\title{
Fantasy proneness, but not self-reported trauma is related to DRM performance of woman reporting recovered memories of childhood sexual abuse
}

Citation for published version (APA):

Geraerts, E. G., Smeets, E., Jelicic, M., van Heerden, J. H., \& Merckelbach, H. L. G. J. (2005). Fantasy proneness, but not self-reported trauma is related to DRM performance of woman reporting recovered memories of childhood sexual abuse. Consciousness and Cognition, 14(3), 602-612. https://doi.org/10.1016/j.concog.2005.01.006

Document status and date:

Published: 01/01/2005

DOI:

10.1016/j.concog.2005.01.006

Document Version:

Publisher's PDF, also known as Version of record

Please check the document version of this publication:

- A submitted manuscript is the version of the article upon submission and before peer-review. There can be important differences between the submitted version and the official published version of record.

People interested in the research are advised to contact the author for the final version of the publication, or visit the DOI to the publisher's website.

- The final author version and the galley proof are versions of the publication after peer review.

- The final published version features the final layout of the paper including the volume, issue and page numbers.

Link to publication

\footnotetext{
General rights rights.

- You may freely distribute the URL identifying the publication in the public portal. please follow below link for the End User Agreement:

www.umlib.nl/taverne-license

Take down policy

If you believe that this document breaches copyright please contact us at:

repository@maastrichtuniversity.nl

providing details and we will investigate your claim.
}

Copyright and moral rights for the publications made accessible in the public portal are retained by the authors and/or other copyright owners and it is a condition of accessing publications that users recognise and abide by the legal requirements associated with these

- Users may download and print one copy of any publication from the public portal for the purpose of private study or research.

- You may not further distribute the material or use it for any profit-making activity or commercial gain

If the publication is distributed under the terms of Article 25fa of the Dutch Copyright Act, indicated by the "Taverne" license above, 


\title{
Fantasy proneness, but not self-reported trauma is related to DRM performance of women reporting recovered memories of childhood sexual abuse
}

\author{
Elke Geraerts ${ }^{\text {a,* }}$, Elke Smeets ${ }^{\mathrm{b}}$, Marko Jelicic ${ }^{\mathrm{b}}$, Jaap van Heerden ${ }^{\mathrm{a}}$, \\ Harald Merckelbach ${ }^{\mathrm{c}}$ \\ a Department of Neurocognition, University of Maastricht, P.O. Box 616, 6200 MD, Maastricht, The Netherlands \\ ${ }^{\mathrm{b}}$ Department of Experimental Psychology, University of Maastricht, Maastricht, The Netherlands \\ ${ }^{\mathrm{c}}$ Department of Experimental Psychology and Faculty of Law, University of Maastricht, Maastricht, The Netherlands
}

Received 15 December 2004

Available online 26 February 2005

\begin{abstract}
Extending a strategy previously used by Clancy, Schacter, McNally, and Pitman (2000), we administered a neutral and a trauma-related version of the Deese-Roediger-McDermott paradigm to a sample of women reporting recovered $(n=23)$ or repressed memories $(n=16)$ of childhood sexual abuse (CSA), women reporting having always remembered their abuse $(n=55)$, and women reporting no history of abuse $(n=20)$. We found that individuals reporting recovered memories of CSA are more prone than other participants to falsely recalling and recognizing neutral words that were never presented. Moreover, our study is the first to show that this finding even held when trauma-related material was involved. Correlational analyses revealed that fantasy proneness, but not self-reported traumatic experiences and dissociative symptoms were related to false recall and false recognition.
\end{abstract}

(c) 2005 Elsevier Inc. All rights reserved.

Keywords: Recovered memories; False memories; Repressed memories; Childhood sexual abuse; DRM task; Fantasy proneness; Dissociation

\footnotetext{
* Corresponding author. Fax: +31 433884125.

E-mail address: E.Geraerts@Psychology.Unimaas.NL (E. Geraerts).
} 


\section{Introduction}

McNally, Clancy, and their colleagues were among the first to apply experimental methods to investigate memory functioning in women reporting repressed and recovered memories of childhood sexual abuse (CSA). In one of their studies, Clancy, Schacter, McNally, and Pitman (2000) made use of the Deese-Roediger-McDermott (DRM) task (Deese, 1959; Roediger \& McDermott, 1995), a paradigm that is very effective in eliciting false memories. In the DRM paradigm, participants study a list of words that are strong semantic associates of a word not presented on the list - the critical lure. For example, participants may study words like bed, rest, awake, tired, and so forth, all of which are strongly related to the nonpresented critical item, sleep. On a subsequent test, participants often falsely recall and recognize the critical lure (e.g., sleep).

Clancy et al. (2000) used this paradigm to examine whether participants reporting recovered memories of CSA would be more prone than others to develop false memories in the DRM paradigm. In their study, control women reporting no history of abuse, and women reporting recovered, repressed, or continuous memories of CSA underwent the DRM task. Clancy et al. (2000) found that, relative to the other groups, women reporting recovered CSA memories more often falsely recognized the nonpresented critical lures. This suggests that these women relied more on memory for gist than on verbatim memory traces of the individual words they had studied (e.g., Brainerd \& Reyna, 1998). Two further studies employed the DRM paradigm to examine memory functioning in people reporting traumatic experiences. Bremner, Shobe, and Kihlstrom (2000) studied women with continuous memories of CSA who were suffering from posttraumatic stress disorder (PTSD). The authors found that these women displayed a higher frequency of false recognition than abused women without PTSD. Zoellner, Foa, Brigidi, and Przeworski (2000) reported that victims of criminal assaults with or without PTSD more often falsely recalled critical nonpresented words than did nontraumatized participants. Thus, the literature on DRM performance of people reporting traumatic experiences allows for two interpretations. On the one hand, one could argue that the raised frequencies of false recall in people with recovered memories show that they are especially susceptible to develop pseudomemories. On the other hand, there are indications that people who have been traumatized exhibit memory impairments of which heightened levels of false recall on the DRM paradigm might be a manifestation (Zoellner et al., 2000).

Although the DRM paradigm creates striking memory illusions, Freyd and Gleaves (1996) questioned the relevance of the DRM paradigm to real world examples of alleged false memories (e.g., in recovered CSA memories or eyewitness testimony). They noted that the real world scenarios where false memories may occur typically involve highly emotional events (e.g., CSA), whereas words used in the DRM paradigm are not emotionally charged and hence not trauma-related. Freyd and Gleaves (1996) hypothesized that the frequency of false recall and recognition in the DRM paradigm would be lowered when trauma-related items would be used, due to their emotional distinctiveness. Our study is the first to address this issue by employing neutral and traumarelated DRM lists to traumatized individuals. We investigated whether participants who reported having recovered CSA memories displayed higher rates of false recall and recognition for neutral and trauma-related words relative to other participants.

A subsidiary aim of our study concerned the issue of whether certain traits are associated with performance on the DRM task. More specifically, we examined whether individual differences in fantasy proneness and dissociation are connected to false recall and recognition in the DRM task. 
It might be speculated, for example, that people who are, possibly due to heightened levels of fantasy proneness, predisposed to false memory effects in the DRM task, would also be predisposed to have pseudomemories. Conversely, CSA might create dissociative tendencies that may lead to enhanced false memory effects on the DRM task. Previous research, for example, has shown that people scoring high on the Dissociative Experiences Scale (DES; Bernstein \& Putnam, 1986) are susceptible to memory distortions induced by various laboratory tests (e.g., Eisen \& Lynn, 2001), including the DRM paradigm (Clancy et al., 2000; Winograd, Peluso, \& Glover, 1998). A number of authors have noted that there is a considerable overlap between dissociation and fantasy proneness (e.g., Merckelbach \& Muris, 2001; Rauschenberger \& Lynn, 1995). We also obtained participants' scores on the Childhood Trauma Questionnaire (CTQ; Bernstein et al., 2003). If false memories in the DRM paradigm are a manifestation of memory impairment due to traumatization, one would expect a robust correlation between false memories on the DRM task and CTQ scores. If, on the other hand, the DRM paradigm primarily taps susceptibility to pseudomemories, one would expect a significant association between such false memories and fantasy proneness.

\section{Method}

\subsection{Participants}

Following the procedure of Clancy et al. (2000), we recruited participants through advertisements in local newspapers. In these advertisements, we invited women to come to our lab when they (a) had recovered CSA memories, (b) believed they had been sexually abused as a child, (c) had a history of sexual abuse which had never been forgotten or (d) had no history of sexual abuse. The study was described as a research project on memory and personality. The study was approved by the standing Ethical Committee of the Faculty of Psychology, University of Maastricht.

After providing written informed consent, a semi-structured memory interview was conducted to classify participants into one of the groups (see also Clancy et al., 2000). Individuals reporting repressed, recovered, and continuous memories of CSA were asked whether they had obtained information from others (e.g., sibling) or had physical evidence (e.g., letters, medical records) that could validate the CSA memories.

\subsubsection{Recovered memory group}

The recovered memory group consisted of 23 women (mean age $=41.6$ years, $S D=10.9$ ) who said having previously forgotten and subsequently recalled memories of CSA. Eight participants $(35 \%)$ had recovered memories of CSA during psychotherapy. Most of the other women in this group recovered memories of CSA after having been exposed to certain cues (e.g., a friend who tells about CSA experiences, the birth of their own child). The majority (22 women; 96\%) reported that their recovered memories had a significant impact on their lives. Only one participant could give corroborative evidence for the abuse, namely a statement of the perpetrator himself. However, in most cases, women lost contact with their families after having confronted them with recovered CSA memories. 


\subsubsection{Repressed memory group}

The repressed memory group comprised 16 women (mean age $=43.9$ years, $S D=6.8$ ) who believed that they had been sexually abused as a child, but had no explicit autobiographical memories of CSA. These women cited a diversity of symptoms they thought indicated a history of CSA (e.g., relationship problems, depressive symptoms, and eating disorders). Some reported vague feelings of nervousness when they were near certain relatives who, they believed, might had abused them. The majority (13 women; $81 \%)$ of this group reported that their CSA had a traumatic impact on their lives. It was, of course, impossible for us to determine whether they had been abused. The term 'repressed memory' describes their belief.

\subsubsection{Continuous memory group}

The continuous memory group comprised 55 women (mean age $=43.1$ years, $S D=14.4$ ) who said that they had never forgotten their abuse. Forty-five $(82 \%)$ women reported that their CSA could be seen as traumatic. Nineteen (35\%) provided the name of a person who could corroborate the abuse (e.g., a sibling who had been abused at the same time, the perpetrator himself). One participant gave us a court document that stated that her father had been indicted for sexually abusing her. Some women in this group indicated that witnesses who could provide evidence for the CSA had deceased.

\subsubsection{Control group}

The control group comprised 20 women (mean age $=41.5, S D=12$ ) who said that they had neither during childhood nor during adulthood ever been sexually abused.

\subsection{Measures}

A number of self-report scales and tasks were administered to the sample. Here, we only discuss those that are directly relevant to the issue of DRM performance and its correlates.

\subsubsection{Self-report scales}

The Dissociative Experiences Scale (DES; Cronbach's $\alpha=.92$; Bernstein \& Putnam, 1986) is a 28 -item self-report measure that asks respondents how often they experience dissociative symptoms like derealization and depersonalization. Items are scored on 100-mm Visual Analogue Scales (VASs). Scores are summed to obtain a total DES score (range 0-100), with higher scores indicating higher dissociative tendencies. The DES exhibits high internal consistency and test-retest correlations ranging from .74 to .84. Van IJzendoorn and Schuengel (1996) have shown that the DES has excellent psychometric properties.

The Creative Experiences Questionnaire (CEQ; Cronbach's $\alpha=.79$; Merckelbach, Muris, \& Rassin, 1999) is a measure that is based on Wilson and Barber's (1983) listing of fantasy proneness characteristics. The CEQ includes 25 dichotomous (yes/no) items that cover experiences related to daydreaming, imagining, and intense fantasizing. Psychometric research (for a review, see Merckelbach, Horselenberg, \& Muris, 2001) has shown that the CEQ possesses adequate reliability in terms of internal consistency and test-retest stability. Furthermore, the CEQ has predictive validity in the sense that certain categories of persons who are known to exhibit fantasy-prone 
characteristics (e.g., people with paranormal experiences, amateur actors) display higher scores on this scale than control participants.

The Childhood Trauma Questionnaire (CTQ; Cronbach's $\alpha=.82$; Bernstein et al., 2003) is a widely used psychometrically sound self-report scale of aversive childhood experiences. The short form consists of 25 items that address five areas of childhood maltreatment, namely emotional, physical, and sexual abuse, and emotional and physical neglect. Each area is represented with five items. Items are rated on 5-point scales anchored 1 (never) and 5 (very often). A total CTQ score can be obtained by summing scores on individual items, of which some have to be recoded before the sum can be calculated. A number of recent nonclinical (e.g., Irwin, 2001; Merckelbach, Horselenberg, \& Schmidt, 2002) as well as clinical studies (e.g., Carrion \& Steiner, 2000; Gast, Rodewald, Nickel, \& Emerich, 2001) on trauma and dissociation employed this measure. Moreover, Bernstein, Ahluvalia, Pogge, and Handelsman (1997) showed that the psychometric properties of the CTQ are satisfactory.

\subsubsection{DRM paradigm}

The 10 neutral word lists used in the current study were derived from lists previously employed in our lab (Peters, Jelicic, Haas, \& Merckelbach, submitted). Extensive pilot work showed that they produce rates of false recall and recognition comparable to those reported by Roediger and McDermott (1995). Adopting the procedure of Peters et al., the 10 trauma-related word lists were constructed as follows. For each critical trauma-related lure, we developed a corresponding word list by obtaining the first 15 associates listed in Lauteslager, Schaap, and Schievels' (1986) and van Loon-Vervoorn and van Bekkum (1991) word association norms. For example, the first 5 associates corresponding to assault were rape, police, beating, child, and violence. On all lists, associates were presented in decreasing order of associative strength. The 10 neutral and 10 trauma-related lists were counterbalanced across participants.

The recognition test consisted of 120 words; 60 (30 neutral and 30 trauma-related words) had been presented in the study phase, while 60 (30 neutral and 30 trauma-related) were new items. The 60 studied items were obtained by selecting three items from each list from serial positions 1,8 , and 10. The 60 new items included the 20 critical lures associated with the study words (e.g., needle, assault), 20 (10 neutral and 10 trauma-related) words unrelated to any words on the list, and 20 (10 neutral and 10 trauma-related) words weakly related to words on the list.

\subsection{Procedure}

All participants were tested individually during a session that lasted for approximately $2 \mathrm{~h}$. First, women completed the self-report scales and after a delay of $30 \mathrm{~min}$, they underwent the DRM task. Participants were instructed that they would see several lists of words on a computer screen and that following each list, they would be asked to write down these words. They were told to write down the last few words they had heard (which is a standard instruction for this task) and then to write down the rest of the words they remembered in any order. They were instructed to write down as many words they could remember, provided they were reasonably confident that these words had been on the list (i.e., they were told not to guess). During the study phase, each word remained for $3 \mathrm{~s}$ on the computer screen. Participants were given $2.5 \mathrm{~min}$ to recall each list. After the 20th list, there was a brief conversation lasting 2-3 min. Subsequently, participants were 
given a sheet with the old and new words and they were asked to indicate whether or not each word had appeared on any of the studied lists.

\section{Results}

\subsection{Self-report scores}

Table 1 shows demographic and psychometric data for the subgroups. One-way Analyses of Variance (ANOVAs) revealed that subgroups did not differ significantly in age or educational level: both $F$ s $(3,110)<1.0, n s$. However, subgroups differed significantly with respect to all self-report scales. Both the recovered and repressed memory subgroups reported more dissociative symptoms (DES) than the continuous memory group and the control group (all $t$ 's $>2.1$, all $p$ 's $<.03$ ). Post hoc tests (LSD) indicated that women with recovered, repressed, or continuous CSA memories scored higher on fantasy proneness (CEQ) and childhood trauma (CTQ) than control women reporting no history of abuse (all $t$ 's $>3.8$, all $p$ 's $<.001$ ).

\subsection{Recall}

\subsubsection{Neutral lists}

Correct recall (i.e., mean proportion of recall of studied words), false recall of critical lures and nonstudied words other than the critical lures (i.e., mean proportion of recall of nonstudied critical lures and of nonstudied words other than the critical lures) are shown in Table 2. Because we had no specific predictions about correct recall, we performed ANOVAs followed by post hoc contrasts (LSD). Results revealed that all groups displayed equivalent rates of correct recall: $F(3,110)<1.0, n s$. Participants recalled $56 \%$ of the words presented in the neutral lists correctly.

To test whether recovered memory participants displayed higher levels of false recall than the other groups, we computed the false recall rate (i.e., false recall of critical lures minus false recall of nonstudied words other than the critical lures) and applied contrast weights of $3,-1,-1$, and -1 to the recovered, repressed, continuous, and control subgroups, respectively. Women with recovered memories of CSA had a higher rate of false recall compared to the repressed, continuous, and control group, $t(110)=4.30, p<.001$, effect size $r=.43$.

Table 1

Demographic data and mean scores of subgroups on the DES, CEQ, and CTQ

\begin{tabular}{|c|c|c|c|c|c|c|}
\hline & Recovered $n=23$ & Repressed $n=16$ & Continuous $n=55$ & Control $n=20$ & $F$ & $p$ \\
\hline Measure & $M$ & $M$ & $M$ & $M$ & & \\
\hline Age (years) & $41.6(10.9)$ & $43.9(6.8)$ & $43.1(14.4)$ & $41.5(12.0)$ & .18 & .91 \\
\hline Education (level) & $5.1(1.5)$ & $5.4(1.7)$ & $4.7(1.8)$ & $5.5(1.8)$ & 1.2 & .31 \\
\hline DES & $30.1(19.4)$ & $31.5(11.6)$ & $22.2(12.6)$ & $12.9(9.0)$ & 7.4 & $<.001$ \\
\hline CEQ & $7.7(2.8)$ & $9.4(5.2)$ & $8.2(3.6)$ & $4.2(3.5)$ & 6.5 & $<.001$ \\
\hline CTQ & $39.9(9.9)$ & $35.3(10.3)$ & $37.2(11.3)$ & $25.5(4.4)$ & 8.6 & $<.001$ \\
\hline
\end{tabular}

Note. Educational level varies on a scale from 0 (no primary school) to 8 (university degree). Standard deviations are in parentheses. 
Table 2

Proportion of recalled studied words, critical lures, and nonstudied words other than the critical lure for neutral and trauma-related lists

\begin{tabular}{lllll}
\hline & $\begin{array}{l}\text { Recovered } \\
n=23\end{array}$ & $\begin{array}{l}\text { Repressed } \\
n=16\end{array}$ & $\begin{array}{l}\text { Continuous } \\
n=55\end{array}$ & $\begin{array}{l}\text { Control } \\
n=20\end{array}$ \\
\hline Word type & $M$ & $M$ & $M$ & $M$ \\
Neutral studied words & $.56(.11)$ & $.56(.08)$ & $.55(.11)$ & $.59(.09)$ \\
Neutral critical lures & $.61(.18)$ & $.46(.21)$ & $.42(.18)$ & $.44(.16)$ \\
Neutral nonstudied words other than critical lures & $.14(.19)$ & $.22(.20)$ & $.21(.19)$ & $.14(.12)$ \\
Trauma-related studied words & $.42(.09)$ & $.43(.08)$ & $.42(.11)$ & $.46(.08)$ \\
Trauma-related critical lures & $.20(.10)$ & $.16(.17)$ & $.14(.11)$ & $.13(.13)$ \\
Trauma-related nonstudied words other than critical lures & $.20(.17)$ & $.18(.16)$ & $.13(.08)$ & $.13(.12)$ \\
\hline
\end{tabular}

Standard deviations are in parentheses.

\subsubsection{Trauma-related lists}

ANOVAs followed by post hoc contrasts (LSD) showed that all participants displayed similar rates of correct recall for trauma-related words, $F(3,110)<1.0$, $n s$, with a mean proportion of recall of $43 \%$.

Performing the earlier mentioned contrast analysis on false recall rate, we found a nonsignificant difference between the groups: $t(110)=.84, p>.05$, effect size $r=.19$. Curiously enough, for the trauma-related lists, critical lures were recalled at a low rate of $15 \%$.

\subsection{Recognition}

\subsubsection{Neutral lists}

Hit rate (i.e., mean proportion of correct recognition) and false alarm for critical lures and nonstudied words other than the critical lures (i.e., mean proportion of recognition of nonstudied critical lures and of nonstudied words other than the critical lures) are shown in Table 3. ANOVAs indicated that all groups exhibited similar rates of correct recognition of neutral words, $F(3,110)<1.0, n s$. Overall, studied words were recognized at a rate of $74 \%$.

To test whether recovered memory participants displayed higher rates of false recognition than the other groups, we computed the false recognition rate (i.e., false recognition of critical lures

Table 3

Proportion of recognized studied words, critical lures, and nonstudied words other than the critical lure for neutral and trauma-related lists

\begin{tabular}{lllll}
\hline & $\begin{array}{l}\text { Recovered } \\
n=23\end{array}$ & $\begin{array}{l}\text { Repressed } \\
n=16\end{array}$ & $\begin{array}{l}\text { Continuous } \\
n=55\end{array}$ & $\begin{array}{l}\text { Control } \\
n=20\end{array}$ \\
\hline Word type & $M$ & $M$ & $M$ & $M$ \\
Neutral studied words & $.76(.09)$ & $.75(.09)$ & $.72(.15)$ & $.74(.15)$ \\
Neutral critical lures & $.86(.08)$ & $.78(.17)$ & $.73(.19)$ & $.72(.09)$ \\
Neutral nonstudied words other than critical lures & $.06(.04)$ & $.09(.06)$ & $.04(.03)$ & $.06(.03)$ \\
Trauma-related studied words & $.85(.09)$ & $.79(.15)$ & $.83(.12)$ & $.86(.10)$ \\
Trauma-related critical lures & $.91(.09)$ & $.81(.14)$ & $.74(.17)$ & $.73(.08)$ \\
Trauma-related nonstudied words other than critical lures & $.20(.16)$ & $.19(.14)$ & $.16(.10)$ & $.17(.08)$ \\
\hline
\end{tabular}

Standard deviations are in parentheses. 
minus false recognition of nonstudied words other than the critical lures) and again applied contrast weights of $3,-1,-1$, and -1 to the recovered, repressed, continuous, and control group, respectively. A significant difference was found, $t(110)=3.17, p=.002$, effect size $r=.30$, demonstrating that women with recovered memories of CSA more often falsely recognized critical lures than the other women.

\subsubsection{Trauma-related lists}

The groups showed equivalent rates of accurate recognition for trauma-related words: $F(3,110)<1.0, n s$. Overall, $83 \%$ of the studied words were correctly recognized.

Analysis with contrast weights indicated that women with recovered CSA memories had a higher rate of false recognition of trauma-related critical lures than the other groups, $t(110)=2.46$, $p=.015$, effect size $r=.28$.

\subsection{Individual differences and DRM performance}

Table 4 shows Pearson correlations between DRM scores, dissociation, fantasy proneness, and childhood trauma. DES scores were significantly associated with unrelated intrusions on recall tests (neutral lists: $r=.23, p<.05$; trauma-related lists: $r=.25, p<.001$ ) and false recognition of unrelated trauma words $(r=.37, p<.001)$. However, correlations between DES and false recall and recognition of critical lures fell short of significance (all $r$ 's $<.16, p$ 's $>.09$ ). CEQ correlated significantly with false recall and recognition of neutral and trauma-related critical lures (all $r$ 's $>.19$, all $p$ 's $<.05$ ). Self-reported childhood trauma (CTQ) did not correlate significantly with any false recall or recognition parameter (all $r$ 's $<.15$, all $p$ 's $>.12$ ).

\section{Discussion}

The purpose of this study was to determine whether women reporting recovered CSA memories would show enhanced false recall and recognition on a neutral and trauma-related version of the

Table 4

Pearson product-moment correlations between dissociative symptoms (DES), fantasy proneness (CEQ), self-reported childhood trauma (CTQ), and recall and recognition parameters

\begin{tabular}{lllll}
\hline & & DES & CEQ & CTQ \\
\hline Recall & Neutral critical lures & .11 & $.21^{*}$ & .10 \\
& Neutral nonstudied words other than critical lures & $.23^{* *}$ & .07 & .09 \\
& Trauma-related critical lures & .10 & $.22^{*}$ & .02 \\
& Trauma-related nonstudied words other than critical lures & $.25^{* *}$ & .01 & .15 \\
Recognition & .10 & $.22^{*}$ & .14 \\
& Neutral critical lures & .09 & .09 & .08 \\
& Neutral nonstudied words other than critical lures & .16 & $.19^{*}$ & .11 \\
& Trauma-related critical lures & $.37^{* *}$ & .05 & .07 \\
\hline
\end{tabular}

\footnotetext{
${ }^{*}$ Correlation is significant at the .05 level (2-tailed).

${ }^{* *}$ Correlation is significant at the .01 level (2-tailed).
} 
DRM paradigm. Our results replicate the robust false recall and recognition effects typically found with the DRM paradigm (Roediger \& McDermott, 1995). That is, overall, participants falsely remembered many of the critical lures. Replicating earlier findings of Clancy et al. (2000), our results also lend support to the idea that women reporting recovered CSA memories are more susceptible than other participants to this memory illusion. More specifically, women with recovered memories of CSA exhibited higher rates of false recall and false recognition of critical lures than the other participants. Our study was the first to show that this was true for both neutral and trauma-related word lists, although the effects were more convincing for recognition than for recall parameters. Taken together, our data are difficult to reconcile with Freyd and Gleaves' (1996) suggestion that the memory illusion tapped by the DRM paradigm would be less strong with trauma-related words, that is, that participants would have fewer false memories when the items are trauma-related relative to neutral items. While recall of trauma-related lures was, indeed, less frequent than recall of neutral lures, false memories did occur and were especially robust in the recognition modality. This smaller effect for recall of trauma-related words may have to do with the emotional salience and distinctiveness of the trauma-related words. This is in line with findings of Pesta, Murphy, and Sanders (2001) that emotional critical lures are subject to false remembering in the DRM task but at a lower rate than neutral critical lures.

A number of researchers have argued that susceptibility to false memories may be due to a deficit in source monitoring, i.e., incorrect judgments about the origin or source of information (Johnson, Hashtroudi, \& Lindsay, 1993). Accordingly, the presentation of semantically associated words activates a concept that is common to all words on the list, namely the critical nonpresented lure. Thus, the DRM paradigm requires participants to differentiate between internally generated thoughts and genuine memories of the studied words (Roediger, Watson, McDermott, \& Gallo, 2001). The present results suggest that women reporting recovered CSA memories may have a source monitoring deficit for all types of material, whether the content is neutral or trauma-related. It can be speculated that especially these women have difficulties with the identification of the origin of a memory and that they may have a tendency to adopt an internally generated thought as being a genuine memory. This could have serious implications, also in everyday life, both in potential impact on the memory and on the development of their knowledge and beliefs. Additionally, it might well be the case that source monitoring confusion can produce pseudomemories. Therefore, it is very important to recognize that the influence of source monitoring on the origin of recovered memories warrants further study. Performance of people with recovered memories in paradigms that explicitly require source monitoring (e.g., false-fame studies, eyewitness suggestibility tests) should be investigated.

In the current study, we also explored whether certain traits are associated with the tendency to develop false memories. Specifically, we examined whether individual differences in dissociation and fantasy proneness were connected to false recall and false recognition on the DRM task. Women who said they had recovered or repressed CSA memories scored higher on the DES than women who indicated they had always remembered their abuse or control women. However, unlike Clancy et al. (2000), we found no significant associations between DES scores and false memories on the DRM paradigm (see for a similar failure: Platt, Lacey, Iobst, \& Finkelman, 1998). This failure could be due to the fact that women in the recovered and repressed memory group had higher scores on the DES than women in the continuous memory and control group, in comparison to equivalent DES scores for all subgroups in the study of Clancy et al. (2000). Moreover, it can 
be speculated that, perhaps, then, dissociative experiences are related to false memories that have a more episodic or autobiographical signature (e.g., Candel, Merckelbach, \& Kuijpers, 2003). On the other hand, fantasy proneness, a close cousin of dissociation, was significantly related to false recall and false recognition. One interpretation of the link between fantasy proneness and false memories is that self-reported traumatic childhood experiences-whether they have been recovered, repressed or are continuously remembered - contribute to fantasy proneness, thereby making traumatized people sensitive to memory illusions like those elicited by the DRM paradigm. Work by Zoellner et al. (2000) and Bremner et al. (2000) seems to support this line of reasoning. Yet, the results of the current study indicate that self-reported traumatic experiences are not related to false recall and false recognition. Note that the CTQ (Bernstein et al., 2003) not only contains items that refer to specific episodes of childhood trauma, but also items that measure the belief or impression that one has experienced aversive childhood events (Merckelbach \& Jelicic, 2004). In sum, then, our data suggest that when it comes to the psychometric correlates of false memories on the DRM paradigm, fantasy proneness rather than self-reported traumatization runs the show. It can be speculated that fantasy proneness includes an ability to associate semantically and hence allowing for more associations which can lead to 'recall' of internally generated thoughts.

Finally, the question arises whether our results have any bearing on the current controversy about recovered/false memories of CSA. Certainly, they lend support that the illusion of remembering events that never happened can happen fairly easily and that cognitive impairments related to recovered memories of CSA enhanced susceptibility for false recall and recognition effects. Of course, the finding that individuals falsely remember having seen a word in a laboratory context does by no means imply that their recovered CSA memories are false. Our results do, however, show that women with recovered CSA memories are, possibly due to a source monitoring deficit, more prone than others to develop certain types of memory distortions, even with trauma-related material.

\section{References}

Bernstein, D. P., Ahluvalia, T., Pogge, D., \& Handelsman, L. (1997). Validity of the Childhood Trauma Questionnaire in an adolescent psychiatric population. Journal of the American Academy of Child and Adolescent Psychiatry, 36, 340-348.

Bernstein, D. P., Stein, J. A., Newcomb, M. D., Walker, E., Pogge, D., Ahluvalia, T., et al. (2003). Development and validation of a brief screening version of the Childhood Trauma Questionnaire. Child Abuse and Neglect, 27, 169-190.

Bernstein, E. M., \& Putnam, F. W. (1986). Development, reliability and validity of a dissociation scale. Journal of Nervous and Mental Disease, 174, 727-735.

Brainerd, C. J., \& Reyna, V. F. (1998). When things that were never experienced are easier to 'remember' than things that were. Psychological Science, 9, 484-489.

Bremner, J. D., Shobe, K. K., \& Kihlstrom, J. F. (2000). False memories in women with self-reported childhood sexual abuse: An empirical study. Psychological Science, 11, 333-337.

Candel, I., Merckelbach, H., \& Kuijpers, M. (2003). Dissociative experiences are related to commissions in emotional memory. Behaviour Research and Therapy, 41, 719-725.

Carrion, V. G., \& Steiner, H. (2000). Trauma and dissociation in delinquent adolescent. Journal of the American Academy of Child and Adolescent Psychiatry, 39, 353-359.

Clancy, S. A., Schacter, D. L., McNally, R. J., \& Pitman, R. K. (2000). False recognition in women reporting recovered memories of sexual abuse. Psychological Science, 11, 26-31. 
Deese, J. (1959). On the prediction of occurrence of particular verbal intrusions in immediate recall. Journal of Experimental Psychology, 58, 17-22.

Eisen, M. L., \& Lynn, S. J. (2001). Dissociation, memory, and suggestibility in adults and children. Applied Cognitive Psychology, 15, S49-S73.

Freyd, J. J., \& Gleaves, D. F. (1996). "Remembering” words not presented in lists: Relevance to the current recovered/ false memory controversy. Journal of Experimental Psychology: Learning, Memory, and Cognition, 22, 811-813.

Gast, U., Rodewald, F., Nickel, V., \& Emerich, H. M. (2001). Prevalence of dissociative disorders among psychiatric inpatients in a German university clinic. Journal of Nervous and Mental Disease, 189, 249-257.

Irwin, H. J. (2001). The relationship between dissociative tendencies and schizotypy: An artefact of childhood trauma?. Journal of Clinical Psychology, 57, 331-342.

Johnson, M. K., Hashtroudi, S., \& Lindsay, D. S. (1993). Source monitoring. Psychological Bulletin, 114, 3-28.

Lauteslager, M., Schaap, T., \& Schievels, D. (1986). Schriftelijke Woordassociatienormen voor 549 Nederlandse zelfstandige naamwoorden [Written word association norms for 549 Dutch words]. Lisse: Swets \& Zeitlinger.

Merckelbach, H., Horselenberg, R., \& Muris, P. (2001). The Creative Experiences Questionnaire (CEQ): A brief selfreport measure of fantasy proneness. Personality and Individual Differences, 31, 987-996.

Merckelbach, H., Horselenberg, R., \& Schmidt, H. (2002). Modeling the connection between self-reported trauma and dissociation in a student sample. Personality and Individual Differences, 32, 695-705.

Merckelbach, H., \& Jelicic, M. (2004). Dissociative symptoms are related to endorsement of vague trauma items. Comprehensive Psychiatry, 45, 70-75.

Merckelbach, H., \& Muris, P. (2001). The causal link between self-reported trauma and dissociation: A critical review. Behaviour Research and Therapy, 39, 245-254.

Merckelbach, H., Muris, P., \& Rassin, E. (1999). Fantasy proneness and cognitive failures as correlates of dissociative experiences. Personality and Individual Differences, 26, 961-967.

Pesta, B. J., Murphy, M. D., \& Sanders, R. E. (2001). Are emotionally charged lures immune to false memory?. Journal of Experimental Psychology: Learning, Memory, and Cognition, 27, 328-338.

Peters, M., Jelicic, M., Haas, N., \& Merckelbach, H. (submitted). Mild executive dysfunctions in undergraduates are related to recollecting words never presented.

Platt, R. D., Lacey, S. C., Iobst, A. D., \& Finkelman, D. (1998). Absorption, dissociation, fantasy proneness as predictors of memory distortion in autobiographical and laboratory-generated memories. Applied Cognitive Psychology, 12, S77-S89.

Rauschenberger, S. L., \& Lynn, S. J. (1995). Fantasy proneness, DSM-III-R axis I psychopathology, and dissociation. Journal of Abnormal Psychology, 104, 373-380.

Roediger, H. L., III, \& McDermott, K. B. (1995). Creating false memories: Remembering words not presented in lists. Journal of Experimental Psychology: Learning, Memory, and Cognition, 21, 803-814.

Roediger, H. L., III, Watson, J. M., McDermott, K. B., \& Gallo, D. A. (2001). Factors that determine false recall: A multiple regression analysis. Psychonomic Bulletin \& Review, 8, 385-407.

Van IJzendoorn, M. H., \& Schuengel, C. (1996). The measurement of dissociation in normal and clinical populations: Meta-analytic validation of the Dissociative Experience Scale (DES). Clinical Psychology Review, 16, 365-382.

van Loon-Vervoorn, W. A., \& van Bekkum, I. J. (1991). Woordassociatie lexicon [Word association lexicon]. Lisse: Swets \& Zeitlinger.

Wilson, S. C., \& Barber, T. X. (1983). Fantasy-prone personality: Implications for understanding imagery, hypnosis, and parapsychological phenomena. In A. A. Sheikh (Ed.), Imagery: Current theory, research, and application (pp. 340-387). New York: Wiley.

Winograd, E., Peluso, J. P., \& Glover, T. A. (1998). Individual differences in susceptibility to memory illusions. Applied Cognitive Psychology, 12, S5-S27.

Zoellner, L. A., Foa, E. B., Brigidi, B. D., \& Przeworski, A. (2000). Are trauma victims susceptible to false memories?. Journal of Abnormal Psychology, 109, 517-524. 